Jan Kozłowski

Uniwersytet Jagiellonski

\title{
Od praczłowieka do Einsteina: rozważania nad ewolucją moralności i umysłu*
}

\section{FROM MAN TO EINSTEIN; REFLECTIONS ON THE EVOLUTION OF MORALITY AND THE MIND}

The article presents an subjective vision of human evolution dating back to man's monkey ancestors. This evolution was very fast took only a few million years. It was started with the transition to the life in an open savannah which created a selection pressure on bipedalism and zooming group. This implied, in turn, the selection pressure on brain development and the growing role of social environment. At a certain stage of development tribes and their culture were formed, and Darwinian evolution was, in the sphere of the mind and customs, replaced by cultural evolution. This evolution was much faster, as it was based on the inheritance of acquired features. Rapid evolution of man was based on positive feedback and did not require the intervention of supernatural powers, such as aliens or God. If God created man, he trusted the mechanisms of evolution, as in the case of other species.

Key words: evolution of man; evolution of the brain size; emergence of the tribal system; reward and punishment system; cultural evolution; emergence of language; beginnings of mathematics.

* Redakcja „Rocznika Teologii Katolickiej” nie podziela poglądów Autora zawartych w niniejszym artykule. 


\section{Błogosławiona zmiana klimatu}

Około 10 milionów lat temu spadek temperatury i ilości opadów spowodował skurczenie lasów tropikalnych Afryki i rozszerzenie sawanny. Zmiana ta zaostrzyła konkurencję pomiędzy małpami człekokształtnymi i pozostałymi, które z braku ogólnej nazwy w języku polskim będę dalej nazywał małpami ogoniastymi, w odróżnieniu od małp człekokształtnych, które ogonów nie posiadają.

Przed zmianą klimatu dominowały małpy człekokształtne, zarówno pod względem liczby gatunków jak i wielkości populacji. Obronne strategie roślin odgrywały rolę w kształtowaniu stosunków dominacji przed i po zmianie klimatu. Rośliny mają organy, które muszą być chronione przed zjedzeniem przez roślinożerców, takie jak liście i niedojrzałe owoce, oraz takie, które muszą być zjedzone dla zwiększenia efektywności rozsiewania nasion, czyli dojrzałe owoce. Większość roślin zawiera substancje o przykrym smaku, takie jak taniny, co zniechęca zwierzęta do jedzenia liści i niedojrzałych owoców. Dojrzewające owoce zwykle zmieniają kolor, co jest sygnałem, że nadają się już do jedzenia, a więc, że taniny już zostały usunięte. Nie jest przypadkiem, że małpy widzą kolory, co w świecie ssaków wcale nie jest tak częste. Odziedziczyliśmy tę zdolność po wspólnych z małpami przodkach. Owoce są pożywnym pokarmem, łatwym do strawienia, ale w tropikach są nierównomiernie rozmieszczone w czasie i przestrzeni, w przeciwieństwie do liści, które można znaleźć zawsze i wszędzie. Małpy człekokształtne są zależne od owoców, choć jedzą też pewne ilości młodych liści, zwykle zawierających mniej tanin. U małp ogoniastych wyewoluowały przystosowania fizjologiczne do diety bogatszej w liście, choć i one oczywiście preferują owoce. Nic nie jest jednak za darmo: małpy ogoniaste trawią powoli i muszą więcej odpoczywać $\mathrm{w}$ trakcie trawienia. Taka fizjologia wymusza ograniczenie wielkości mózgu, organu bardzo kosztownego w utrzymaniu. Małpy ogoniaste mają wprawdzie mózgi większe niż inne ssaki tej samej wielkości, ale relatywnie mniejsze niż małpy człekokształtne.

Ewolucja małp poszła w dwóch kierunkach: małpy ogoniaste odżywiają się w dużym stopniu łatwo dostępnym i trudnym do strawienia pokarmem, czyli liśćmi, a małpy człekokształtne są uzależnione od pożywnych, ale nie zawsze łatwo dostępnych owoców, z pewnym dodatkiem mięsa. Nasiliło to selekcję w kierunku większej inteligencji małp człekokształtnych, wymaganej do odnajdywania rozproszonego pokarmu i zbiorowych polowań na drobne małpy ogoniaste i inne zwierzęta. 
Po skurczeniu się lasów tropikalnych zakończyło się uprzywilejowanie małp człekokształtnych ze względu na rosnącą konkurencję Nauka w dostępie do zasobów. Wskutek tego mniej więcej siedem milionów lat temu pewna populacja (lub populacje) małp człekokształtnych zaczęły w coraz większym stopniu eksploatować otwarte tereny sawanny, inicjując linię ewolucyjną praludzi, a ostatecznie homo sapiens.

Nowe środowisko przyniosło nowe wyzwania, głównie żar bezpośrednich promieni słonecznych i zwiększoną presję drapieżników. To spowodowało ewolucję nowych adaptacji. Dwunożność jest jedną z najważniejszych. Dzięki niej lepsze było chłodzenie przez powiewy wiatru powyżej poziomu traw, a ponadto pozycja taka zmniejsza o około $70 \%$ ilość promieniowania docierającego do ciała w stosunku do pozycji czteronożnej. W powiązaniu z utratą owłosienia i intensywną zdolnością pocenia się powstała zatem wyjątkowa zdolność znoszenia upału. Niestety, ciemny kolor skóry powoduje większą absorpcję słonecznego ciepła, ale jest to kompromis - ciemna skóra chroni przed szkodliwym, rakotwórczym działaniem promieni ultrafioletowych. Dwunożność miała jednak inne zalety, bardzo istotne dla historii linii ewolucyjnej prowadzącej do człowieka - uwolnienie górnych kończyn umożliwiało transport broni - początkowo odpowiednich kijów, a współcześnie pistoletów maszynowych, a także narzędzi. Małpy człekokształtne używają wprawdzie prostych narzędzi, ale muszą ich za każdym razem szukać w najbliższym otoczeniu.

Dieta małp człekokształtnych żyjących na sawannie także musiała się zmienić. Owoce są tu rzadkie, nasiona i organy przetrwalnikowe roślin też niezbyt obfite. Pozostają zatem owady i mięso kręgowców, na początku najprawdopodobniej padlina, później efekt zbiorowych polowań. Konkurencja o padlinę jest na sawannie szczególnie ostra i tylko zorganizowane grupy hominidów mogły odpędzić drapieżniki i padlinożerców. Prawdopodobnie najgroźniejszym konkurentem był lampart, jedyny drapieżnik sawanny broniący swego łupu przez dłuższy czas, poprzez wciągnięcie na drzewo. Wiele czaszek hominidów nosi ślady wskazujące, że mogły to być ofiary lamparta broniącego swej zdobyczy.

Życie w zorganizowanych grupach zmniejszało zagrożenie ze strony drapieżników - któryż z nich zdecyduje się zaatakować większą grupę uzbrojoną w kije, wydającą skoordynowane dźwięki? Na pewno istniał silny nacisk selekcji na powiększanie grup, ale w przyrodzie nic nie jest za darmo. Życie w dużych grupach, powiedzmy 20-40 osobników, utrzymujących ze sobą kontakty socjalne, zarówno wrogie - co nieuniknione - jak i przyjacielskie, wymaga sporej inteligencji, a ta - sporego 
mózgu. Mózg jest kosztownym organem - u człowieka stanowi zaledwie $2 \%$ masy ciała, a pochłania około $20 \%$ budżetu energetycznego.

\section{Dlaczego duży mózg jest tak ważny w życiu socjalnym?}

Ukrywanie się przed drapieżnikiem jest powszechne w przyrodzie, ale ukrywanie się za plecami innych może być jedyną strategią na otwartych obszarach sawanny albo w otwartych wodach czy powietrzu, gdzie brak fizycznych kryjówek. Jeśli drapieżnik zaatakuje grupę, ryzyko śmierci rozdziela się na wiele osobników, a więc ryzyko śmierci pojedynczego zwierzęcia maleje. Dodatkowo te, które potrafią znaleźć sobie miejsce w środku grupy, są szczególnie bezpieczne.

Zwierzęta żyjące w stadach nie muszą być powiązane osobistymi więzami, bo często nie bronią się zbiorowo, a więc „nie nadstawiają karku" za innych. Takie stada nazywamy dlatego stadami anonimowymi. Mogą one być ogromne. Wystarcza prosty układ nerwowy, by korzystać z komfortu bezpieczeństwa przebywania w takim stadzie. Trzeba imitować tylko zachowanie innych - gdy poruszające się stado zmienia kierunek, konieczne jest dostatecznie szybkie zmienienie własnego kierunku, by ani na chwilę nie znaleźć się na niebezpiecznych peryferiach. Ucieczka lub nieskoordynowane ataki stanowiły metodę obrony. Jednak grupy małp, nie są anonimowymi stadami i zachowują się lub zachowywały zupełnie inaczej w chwili ataku drapieżników. Wspólna obrona, polegająca na skoordynowanych i przemyślanych działaniach, oparta jest na więziach osobistych między członkami grupy. W takich zbiorowiskach, przynajmniej okresowo, występują napięcia i spory. Wśród małp powstają koalicje oparte o altruizm krewniaczy i odwzajemniony, a koalicje takie pomagają w zdobyciu pozycji społecznej. Bycie członkiem silnej koalicji jest często ważniejsze od siły mięśni. Tak skomplikowane zachowania wymagają zaawansowanego systemu nerwowego, stąd nacisk selekcji na rozwój mózgu. Takie same reguły dotyczyły zapewne także wczesnych hominidów.

Na pewnym etapie rozwoju mózgu zaczyna funkcjonować teoria umysłu, pozwalająca przewidywać zachowanie innych członków grupy. Jeden z członków grupy wyobraża sobie motywacje i możliwe reakcje innych partnerów. Teoria umysłu może być wielopiętrowa. Najniższy poziom to refleksja nad własnymi myślami - ,ja myślę, że...”. Nieco wyższy poziom to „ja myślę, że on myśli ...”, co pozwala przedsięwziąć odpowiednią akcję. Jeszcze wyższy poziom to ,ja myślę, że on myśli, że ja myślę ..." itd., jednak nawet nie wszyscy ludzie współcześni są w stanie dojść do piątego stopnia bez posługiwania się notatkami. 
Małpy najprawdopodobniej są jedynie zdolne do stosowania ,ja myślę, że on myśli...", choć zapewne są wyjątkowo zdolne osobniki, mogące Nauka iść o jeden szczebel wyżej. Teoria umysłu umożliwia empatię. Jej brak - niezdolność do wyobrażenia sobie, że ktoś inny myśli inaczej lub ma inną wiedzę o tej samej sprawie - jest jednym z objawów autyzmu.

Życie społeczne jest zawsze bardzo skomplikowane. Jak pokazuje Robin Dunbar ${ }^{1}$, wielkość grupy musi być skorelowana z wielkością mózgu i dlatego pierwsze hominidy nie mogły tworzyć grup większych niż 20-30 osób. Zapewniało to pewien stopień bezpieczeństwa dzięki możliwości odstraszania drapieżników oraz umożliwiało skuteczniejsze polowania na większą zwierzynę, ale zapewne ciągle istniał nacisk selekcji na dalszy wzrost liczebności grupy i wielkości mózgu. Dzięki większemu udziałowi mięsa w diecie pewne powiększenie rozmiarów mózgu było zapewne możliwe, ale znów pojawiła się bariera energetyczna.

\section{Mózg użyteczny, ale bardzo kosztowny organ}

Gwałtowne powiększanie mózgu wystąpiło, gdy homo erectus nauczył się, jak kontrolować ogień, a przede wszystkim jak używać ognia do przyrządzania potraw. Ta zdolność wyłoniła się 700000 do 400000 lat temu, choć okazjonalne wykorzystywanie ognia, zapewne naturalnego pochodzenia, wydaje się nieco starsze. Termiczna obróbka pokarmu roślinnego i zwierzęcego radykalnie poprawiła jego strawność. Dzięki temu możliwe było ograniczenie wielkości przewodu pokarmowego, także bardzo energochłonnego, ale równocześnie dostarczającego substancji odżywczych dla całego ciała, także mózgu.

Selekcja w kierunku zwiększania wielkości grupy, a zatem i mózgu, musiała być u homo erectus bardzo silna, gdyż na horyzoncie pojawił się nowy, bardzo groźny wróg: inne grupy własnego gatunku. Łatwiej pokonać czy odstraszyć nawet najgroźniejszego drapieżnika niż zdeterminowaną konkurującą grupę. A zapewne populacja homo erectus szybko zapełniała przestrzeń, gdyż ogień rozwiązał ostatecznie problem obrony przed drapieżnikami nocą. Pojawiła się jednak nowa bariera dla powiększania mózgu: duża czaszka noworodka utrudniała poród, czyniąc go bolesnym i niebezpiecznym, często niemożliwym bez pomocy innych kobiet. To fizyczne ograniczenie zahamowało możliwości rozwoju mózgu w łonie matki, ale selekcja w kierunku zwiększania mózgu dalej trwała, bo bez dalszego powiększenia mózgu

R. Dunbar, Grooming, Gossip and the Evolution of Language, Harvard 1996. Polskie tłumaczenie: Pchty, plotki a ewolucja języka, tłum T. Pańkowski, Warszawa 2009. 
powiększanie grup i wzrost złożoności życia społecznego byłyby niemożliwe. Było tylko jedno możliwe rozwiązanie tego ewolucyjnego dylematu: przesunięcie znacznej części rozwoju mózgu na okres postnatalny. Mózgi innych ssaków po urodzeniu rosną znacznie wolniej niż mózg człowieka. Jednak rozwój mózgu po urodzeniu jest procesem powolnym, trwającym wiele lat. Oznacza to radykalne przedłużenie dzieciństwa, a więc okresu całkowitej zależności od rodziców. Jest to niebezpieczne, bo rodzice mogą umrzeć lub zginąć przed osiągnięciem samodzielności przez dziecko. Ryzyko to było zapewne łagodzone przez znajomość genealogii, a zatem i stosunków pokrewieństwa, co dawało szansę przeżycia sierotom lub półsierotom. Długie dzieciństwo miało też dobrą stronę, gdyż pozwalało na intensywne uczenie się, nie tylko sposobów zdobywania pokarmu i innych codziennych czynności, ale także skomplikowanych reguł życia społecznego. Te ogromne zmiany następowały zapewne stopniowo i miały istotne konsekwencje, zwłaszcza dla zachowań związanych z rozrodem.

\section{Wielki wynalazek - plemię}

Nasi przodkowie żyli zapewne w grupach składających się z kilku-kilkunastu monogamicznych lub częściowo poligamicznych rodzin, najprawdopodobniej złożonych z silnie spokrewnionych osobników ${ }^{2}$. We wczesnych etapach ewolucji człowieka, jeszcze grubo przed pojawieniem się homo erectus, życie społeczne w takich grupach było kształtowane w oparciu o altruizm krewniaczy i altruizm odwzajemniony, występujące powszechnie także w świecie zwierząt. Zwierzęta żyjące w tego typu grupach muszą się zmierzyć z poważnym problemem, jak uniknać chowu wsobnego, czyli krzyżowania w pokrewieństwie, gdyż znacznie zwiększa on szanse wystąpienia chorób genetycznych. Zwykle ten problem jest rozwiązywany bardzo prosto - dojrzewające osobniki jednej płci, najczęściej samce, opuszczają stado, albo dobrowolnie, albo są z niego wypędzane. Obcy samiec musi znaleźć sposób, by zostać zaakceptowanym przez grupę niespokrewnionych osobników ${ }^{3}$. Jako niezbyt chlubny przykład można podać stado lwów

\footnotetext{
2 Możemy o tym wnioskować na podstawie znajomości zwyczajów ostatnich współczesnych grup zbieracko-łowieckich.

3 W artykule A papionin multilevel society as a modelfor hominin social evolution, opublikowanym w "International Journal of Primatology", 33/2012, Larissa Swedell i Thomas Plummer twierdzą, że struktura socjalna pawianów z gatunku Papio hamadryas może najbardziej przypominać stosunki w grupach wczesnych hominidów. Samce tworzą klany złożone z wielu grup, a dojrzewające samice są zmuszane do przejścia do innej grupy w obrębie klanu.
} 
składające się zwykle z dwóch dorosłych samców, grupy spokrewnionych między sobą samic i młodzieży, przy czym dorastające samce Nauka opuszczają stado. Młode samce tworzą „bandy” szukające okazji przejęcia stada, co zdarza się zwykle, gdy jeden z dorosłych samców zdechnie. Nowi panowie stada zabijają wtedy wszystkie noworodki, gdyż nie są one z nimi spokrewnione, a skrócenie okresu karmienia przyspiesza ruję matek. Nie jest jasne, jak wczesne hominidy unikały chowu wsobnego. Być może grupy nie były stałe, część rodzin przemieszczała się pomiędzy grupami. Znajomość genealogii była istotna dla ochrony przed chowem wsobnym i zapewne rozwinęła się dość wcześnie, choć wymagała stosunkowo zaawansowanego mózgu. Kto wie, czy zdolność pamiętania genealogii nie była jednym z mechanizmów napędowych jego rozwoju

Grupy hominidów nie żyły w próżni. Otoczone były innymi grupami i musiały wchodzić z nimi w interakcje, czasem wrogie, a czasem prowadzące do kooperacji, sojuszów lub przynajmniej tolerancji. Możemy sobie wyobrazić, że zaczęły pojawiać się proste negocjacje na temat dzielenia zasobów, przede wszystkim wody, ale także wymiany dziewcząt i chłopców (może jeszcze młodych samców i młodych samic) w celu zawierania związków małżeńskich. Prawdopodobnie niektóre osoby miały większy talent negocjacyjny lub talent do swatania, podobnie jak w świecie współczesnym. Napięcia zapewne były, bo za negocjatorami stali wojownicy, naładowani agresją. Ale do dziś, zarówno w świecie ludzi jak i zwierząt, jakieś formy negocjacji poprzedzają (gdy nieudane) lub zastępują (jeśli udane) agresję. Walki są zawsze kosztowne, dlatego lepiej zacząć od negocjacji.

Kooperujące grupy stawały się coraz bardziej powiązane więzami pokrewieństwa, co zwiększało ich sukces w konkurencji z innymi grupami, mniej nastawionymi na kooperację. Takie kooperujące grupy, klany, mogły być zarodkami organizacji plemiennej. Trwałość klanu wymaga powstania mechanizmów integrujących, takich jak wspólne rytuały, mity, wiedza, reguły, tabu, czy przesądy. Mechanizmy te sa bazą dla rozpoznania kto jest swój - inny członek plemienia, a kto obcy. Zbiór reguł pozwala też eliminować „,jeźdźców na gapę" Są to członkowie grupy, którzy nie odwzajemniają zachowań altruistycz-

$4 \quad$ Wiedza, kto jest kuzynem pierwszego rzędu, była wystarczająca z punktu widzenia zapobiegania skutkom chowu wsobnego. Kuzyni tacy są spokrewnieni w 1/8. Prawdopodobieństwo wystąpienia dziedzicznych chorób w przypadku dzieci powstających w związkach dalszych kuzynów, spokrewnionych w 1/16 lub mniej, niemal nie różni się już od prawdopodobieństwa wystąpienia tych chorób u dzieci w związkach ludzi niespokrewnionych. 
nych czy innych wymagających wysiłku zachowań dobrych dla grupy, a korzystają z dobrodziejstw, jakie daje życie w grupie. Zjawisko ,jazdy na gapę" jest zawsze groźne i rozsadza wiele układów społecznych, także współcześnie. Jedynym sposobem jest karanie albo eliminowanie ich z grupy, co w tamtych czasach było prawie równoznaczne z wyrokiem śmierci. We współczesnych społeczeństwach, gdzie żyjemy w dużych grupach osób nie zawsze znających się osobiście, próbujemy z umiarkowaną skutecznością walczyć ze zjawiskiem „jazdy na gapę" przy pomocy przepisów prawnych ${ }^{6}$.

Duże klany mogły się rozpadać, nie tracąc całkowicie ze sobą związku. Małe klany mogły się łączyć, zawierając różnorodne sojusze. Na pewnym etapie, niestety trudnym do umiejscowienia w ewolucyjnej historii człowieka, pojawiły się związki klanów, które można już nazwać plemionami. Członkowie plemion byli już słabiej spokrewnieni i rzadziej spotykali się spontanicznie, stąd niezbędne stało się organizowanie świąt dających okazje do zbiorowego pielęgnowania rytuałów, ustalania wspólnych reguł, itp. Można powiedzieć, że na tym etapie dalszy rozwój mózgu był w dużej mierze nakierowany na pielęgnowanie kultury?

Wyobraźmy sobie, że grupa hominidów gromadzi się o zmierzchu dookoła ogniska. Upiekli mięso czy bulwy roślin i ucztowali, teraz mają czas na odpoczynek. Ale czy dobrodziejstwo ognia to tylko możliwość przyrządzenia łatwostrawnego posiłku? Ludzie potrzebują przeciętnie 8 godzin snu, a noc w tropikach trwa około 12 godzin bez względu na porę roku. Bez ognia te cztery nadmiarowe godziny były spędzane w chłodzie i lęku przed drapieżnikami. Te same cztery godziny spędzone dookoła ogniska pozwalały oszczędzać energię niezbędną dla termoregulacji, co umożliwiało lepsze „karmienie” energochłonnego mózgu, ale także dały szansę na kultywowanie życia społecznego ${ }^{8}$. Niewiele zmieniło się od tamtego czasu - ciągle kochamy ogień, choć

$6 \quad$ Niestety prawo działa powoli. Jeszcze kilkadziesiąt lat temu skuteczny był ostracyzm - eliminacja z grupy towarzyskiej łączyła się z przykrymi, a często kosztownymi, konsekwencjami. Dziś dominuje chęć wyróżnienia się, nieważne czy pozytywnym czy negatywnym zachowaniem, a eliminacja z jednej grupy nie jest groźna, bo łatwo znaleźć inną grupę. Wiele niepokojących zjawisk społecznych jest zapewne wynikiem zmiany struktury społecznej. Wypracowanie nowych sposobów ograniczania ,jazdy na gapę"wymaga starannego i uczciwego przemyślenia, uwzględniającego nasze ewolucyjne korzenie. London 2012. 
ognisko jest często zastępowane przez kominek lub grill. Niestety, jakże często oglądając telewizję trwonimy ten cenny czas po zapad- Nauka nięciu zmroku, zwłaszcza, gdy oglądamy programy w samotności i nie możemy poprzez wspólne komentowanie z bliskimi traktować historii z ekranu jak opowieści przy ognisku. Głód intensywnych kontaktów społecznych usiłujemy zaspokoić komunikacją elektroniczną, dobrze jeśli ze znajomymi, gorzej jeśli z pseudoznajomymi z portali społecznościowych, co często daje fałszywe tylko poczucie bycia w grupie. $\mathrm{Z}$ kolei jasne oświetlenie kradnie nam te cenne cztery godziny także w inny sposób - możemy dłużej pracować, a dla zaspokojenia potrzeb społecznych kradniemy kolejne godziny przeznaczone na sen.

Organizacja plemienna zainicjowała nowy rodzaj presji selekcyjnej, którą będę nazywał „,selekcją socjalną”. Jeśli środowisko społeczne staje się ważniejsze niż środowisko naturalne, mechanizmy społeczne zmuszają osobniki do częstych zachowań dobrych dla grupy, nawet wtedy, jeśli są one niekorzystne z punktu widzenia osobnika. Selekcja socjalna nie jest dosłownie selekcją grupową w tradycyjnym sensie, ponieważ każdy osobnik w dalszym ciągu maksymalizuje szansę rozprzestrzenienia swoich genów, ale najlepszą drogą dla osiągnięcia tego celu w konkretnym środowisku społecznym jest przestrzeganie reguł ustanawianych przez grupę, przynajmniej wtedy, jeśli grupa potrafi dobrze bronić się przed ,jeźdźcami na gapę”. Taki mechanizm będzie działać, o ile koszt życia w grupie jest niższy niż koszt opuszczenia grupy.

\section{Rola nagrody i kary}

Skomplikowane sytuacje wymagają skomplikowanych i wielowymiarowych analiz dla znalezienia optymalnych rozwiązań. Zwiększają one efektywność rozprzestrzeniania genów danego osobnika, zarówno bezpośrednio poprzez rozród jak i przez pomaganie krewnym, nosicielom z określonym przez współczynnik pokrewieństwa prawdopodobieństwem takich samych genów. Jednak co jest ewolucyjnie optymalne, niekoniecznie musi tak być postrzegane przez osobnika. Wyobraźmy sobie dwie alternatywne strategie. Strategia A daje 20 osobników potomnych z prawdopodobieństwem 0,2 , co oznacza, że $80 \%$ stosujących tę strategię nie będzie miała potomstwa, a $20 \%$ będzie miało 20 potomków. Strategia B daje tylko 6 potomków, ale z prawdopodobieństwem 0,5 , co oznacza, że połowa osobników będzie miała 6 dzieci, a połowa nie będzie miała dzieci wcale (np. zginie przed osiągnięciem dojrzałości). Strategia A daje przeciętnie czterech potomków 
(20 razy 0,2$)$, a strategia $\mathrm{B}$ trzech (6 razy 0,5$)$. W populacji powinna rozprzestrzeniać się strategia A. Ale jest problem, bo powoduje ona, że $80 \%$ osobników czuje się przegrana, a w strategii B jest ich tylko $50 \%$. W świecie zwierząt o ograniczonych możliwościach retrospekcji to nie jest przeszkoda, ale w świecie istot rozumnych? Kto chce być przegranym? Jeśli posiadanie dzieci jest uważane za nagrodę, a nieposiadanie za karę, a z pewnością tak było u naszych przodków i jest do dziś wśród ludów afrykańskich ${ }^{9}$, brak dzieci będzie powodować frustrację, często nasilaną przez reakcję społeczną, zwłaszcza matek i babć. Jest bardzo prawdopodobne, że w takich społeczeństwach strategia B będzie częściej wybierana, mimo iż jest ona nieoptymalna z punktu widzenia rozprzestrzeniania genów. Tego typu napięcia między maksymalizacją rozprzestrzeniania genów i osobistą satysfakcją były zapewne powszechne u naszych przodków z chwilą, gdy zaczęli oni zdawać sobie sprawę ze swej indywidualności i niepowtarzalności. Jest to napięcie, które pozostało do dziś.

Nawet najinteligentniejsze zwierzęta nie robią formalnych obliczeń jak zmaksymalizować rozprzestrzenianie swych genów. W praktyce muszą być stosowane uproszczone reguły i systemy oparte na intuicji, które może nie są całkiem precyzyjne, ale w przybliżeniu pomagają realizować podstawowy ewolucyjny cel. Bezpośrednią motywacją zwierząt, by jeść nie jest chęć przeżycia, a uprawiania seksu - chęć rozmnożenia się. Jedzą, by odczuć przyjemność nasycenia lub przynajmniej zlikwidować lub ograniczyć dyskomfort powodowany głodem. Kopulują dla przyjemności lub zmniejszenia napięcia. W mózgach nie wyewoluowały algorytmy, tylko układ nagrody i kary.

Układ nagrody i kary działa na ogół bardzo dobrze na poziomie indywidualnym, a brak odczuwania przyjemności z jedzenia lub seksu jest zwykle objawem zaburzeń somatycznych lub psychicznych. Małpy człekokształtne (z wyjątkiem orangutana) i ludzie, są zwierzętami niezwykle socjalnymi: wygnanie lub zagubienie się jest często niemal wyrokiem śmierci. Przynależność do grupy, akceptacja, iskanie lub jego substytuty, są źródłem przyjemności. Wprawdzie w grupie częste są przejawy agresywnych zachowań, zwłaszcza ze strony osobników stojących wyżej w hierarchii, ale nawet tak zachowujące się osobniki zwykle po chwili wysyłają sygnały, które nazywamy „wyciąganiem ręki do zgody". W przypadku małp jest to zwykle iskanie, którego wymowę można by przetłumaczyć: „W porządku, generalnie to ja cię akceptuje, no ale zdarzyło się, zresztą zasłużyłeś sobie...". Szympansy bonobo

$9 \quad$ Jest to przyczyna, dla której celibat księży, a więc przynajmniej formalnie wyrzeczenie się potomstwa, jest w Afryce całkowicie niezrozumiały. 
prócz iskania używają w celu łagodzenia napięć między osobnikami seksu, uprawianego zarówno z partnerem tej samej jak i odmiennej Nauka płci. Ludzie mają bogaty repertuar proszenia o przebaczenie. Do łagodzenia napięć w grupie używane jest plotkowanie (choć rola plotek jest znacznie szersza), czy też opowiadanie dowcipów.

W wielu przypadkach efekty danego zachowania mają dwa aspekty, podobnie jak używanie kart kredytowych: bezpośredni skutek i przyszłe konsekwencje. Nie ma problemu, jeśli oba efekty, natychmiastowy i przyszły, są nagradzane lub karane. Gorzej, jeśli efekt natychmiastowy jest nagradzany, a przynosi fatalne skutki w przyszłości. Nieostrożny użytkownik karty kredytowej ma przyjemność z zakupu, ale może mieć później kłopoty ze spłaceniem zadłużenia. Przy podejmowaniu decyzji powinno się brać pod uwagę zarówno aktualną nagrodę jak i ewentualną przyszłą karę, przy czym ocena tej drugiej wynika zarówno z wcześniejszych doświadczeń jak i osobistych predyspozycji, być może częściowo uwarunkowanych genetycznie. W społeczeństwach dzięki przekazywaniu informacji decyzje mogą zależeć także od doświadczeń zakumulowanych przez grupę.

Rodzice powinni zapobiegać podejmowaniu przez dzieci, nosicieli ich genów, niebezpiecznych akcji, przynoszących jednak chwilową przyjemność. W przeszłości używany był szeroki repertuar kar, dziś znacznie ograniczony przez zakaz stosowania kar cielesnych. Ale pozostał jeden sposób: straszenie. Często przywoływane są najróżniejsze straszydła o regionalnie i pokoleniowo zróżnicowanych nazwach. Jeśli dziecko zrobiło coś niebezpiecznego, ale miało szczęście i nic się nie stało, usłyszeć możemy w Krakowie: „Jeśli zrobisz to jeszcze raz, to przyjdzie bobo i cię zabierze". Na poziomie plemienia straszenie przyjmuje często formę różnych tabu, których złamanie może podlegać bezpośredniej karze, ale także ukaraniu przez siły nadprzyrodzone. Prawdopodobnie nawet $\mathrm{w}$ prymitywnych społeczeństwach zdawano sobie sprawę ze szkodliwych skutków krzyżowania w pokrewieństwie. Ale o ile trudniej wytłumaczyć, że sypianie z siostrą może prowadzić do spłodzenia dzieci upośledzonych lub chorych, niż powiedzieć, że zagniewa to jakiegoś boga czy bogów, którzy ześlą karę.

Dotąd przykłady dotyczyły prostych relacji osobnik - osobnik lub osobnik - środowisko. Ale co z cnotami społecznymi? Jeśli interes indywidualny i grupowy idą w parze, nie jest trudno nauczyć odpowiedniego zachowania poprzez kombinację pochwał, upomnień, kar i straszenia. Prawdziwy problem powstaje wtedy, jeśli interes grupy wymaga poświęceń ze strony jednostki. Czy jest możliwe przetłumaczenie grupowych reguł na układ nagrody i kary działający w naszym 
mózgu? Na jakimś etapie rozwoju homo sapiens powstały pojęcia szacunku i honoru. Bycie szanowanym sprawia nam przyjemność, ale by osiągnąć taki status trzeba zaakceptować i pielęgnować takie grupowe cnoty jak odwaga, uczciwość, opanowanie czy szczodrość względem potrzebujących. By wpoić takie cnoty, nie wystarczy straszenie jakimś tam bobo, dziadem, czy innym straszydłem. Potrzebna jest istota o niemal nieograniczonych możliwościach karania i nagradzania. Umysł religijny musiał zatem wyewoluować na którymś etapie rozwoju społeczeństw hominidów bez względu na to, czy Bóg istnieje (bogowie istnieją), czy nie. Obietnice bogów miały moc spełniania się, o ile reguły przez nich wymagane wzmacniały siłę plemienia. Jeśli wymagane jest narażenie życia dla grupy, to bohaterskie zachowania w przypadku szczęśliwego zakończenia zamieniały chwałę na wysoki sukces reprodukcyjny albo poprzez możliwość wyboru atrakcyjnego partnera albo większe szanse na stosunki pozamałżeńskie. Jeśli zakończyły się śmiercią na polu chwały, to nagroda czekała w życiu pozagrobowym, co osłabiało obawę przed bardziej ryzykownymi zachowaniami. Nie bez znaczenia jest też, że chwała poległych z pewnością przenosiła się na ich rodziny, np. synowi czy córce bohatera łatwiej było znaleźć godnego partnera. Teoria umysłu mogła być rozszerzona na teorię umysłu bogów bez wytwarzania dodatkowych obwodów w mózgu. Teoria umysłu bogów pozwalała przewidzieć, co jest im miłe i będzie nagradzane, a co niemiłe i będzie karane. Jeśli takie przewidywania były społecznie trafne, plemię dobrze prosperowało, jeśli nie były trafne, zostawało pokonane, znikało lub było wchłaniane przez innych przyjmując ich system wartości.

Gdzieś w historii człowieka pojawił się odwet. Czy jest to tylko kara, czy coś więcej? Czy odwet jest znany w świecie zwierząt? Czy odwet sprawia przyjemność niektórym ludziom? Czy przyjemność ta wynika z poczucia władzy, a taki stan zwiększa sukces reprodukcyjny? Jest wiele pytań związanych $\mathrm{z}$ tym mechanizmem, działającym nie tylko na poziomie plemion, ale także klanów w obrębie plemienia, czy wreszcie osobników. Wydaje się, że bogowie plemienni lubili odwet w relacjach między plemionami, ale nie potrafili zapobiec odwetowi między klanami, co osłabiało pozycję plemienia ${ }^{10}$.

$10 \quad$ Dojrzałe systemy religijne próbują regulować kwestię odwetu na poziomie wewnątrzplemiennym, ale nie zawsze są skuteczne. 


\section{Ewolucja kulturowa nie jest Darwinowska}

Reguły postępowania w różnych sytuacjach społecznych są przekazywane kulturowo, z modyfikacjami zachodzącymi z upływem czasu. Analogia do ewolucji Darwinowskiej może być myląca, bo te modyfikacje nie zachodzą losowo, jak w przypadku ślepych mutacji. Modyfikacje są podejmowane celowo, dla dostosowania reguł do zmieniającego się świata. Reguły te służą m.in. eliminacji lub neutralizacji „jeźdźców na gapę", tego największego niebezpieczeństwa rozsadzającego społeczeństwa. Istnieje jednak nieustanny wyścig zbrojeń między społeczeństwami i tymi jeźdźcami, gdyż zmieniają oni metody działania, a właściwie oszukiwania. Muszą próbować nadążać za tym zmiany reguł. We współczesnym świecie, gdzie reguły zastąpione zostały przez prawo, mówimy o wykorzystywaniu luk w prawie, co skutkuje uszczegółowianiem prawa, nasilaniem kontroli. „Jeźdźcy na gapę” szukają wtedy innych luk, itd. W czasach osłabienia cnót grupowych, co wynika z anonimowości naszych społeczeństw, przyjęliśmy, że wszystko, co nie jest przez prawo zabronione, jest dozwolone, a równocześnie ograniczyliśmy możliwości stróżów prawa (władza wszelkich szczebli), gdyż ich obowiązuje zasada, że mogą działać tylko w sposób przewidziany prawem. Wniosek: musimy pogodzić się w pewnym zakresie z obchodzenia prawa i wykorzystywaniem przez ,jeźdźców na gapę”.

Ewolucja kulturowa jest z zasady lamarkowska: cechy nabyte są przekazywane następnym pokoleniom. Dlatego jest ona tak szybka. Jednak tendencja do posłuszeństwa względem reguł ma zapewne przynajmniej częściowo podłoże Darwinowskie, oparte na zmienności dziedziczonej w genach. Jeśli tak, to musi istnieć zmienność inklinacji do przestrzegania reguł. Jej rolę omówię w następnym rozdziale.

\section{Zmienność jest niezbędna dla prosperity plemienia}

Zmienność jest podstawą Darwinowskiej ewolucji drogą selekcji naturalnej. Selekcja ta nie produkuje cech de novo. Powoduje ona, że pewne warianty stają się częstsze, a inne rzadsze. Istnieje pewien specjalny typ selekcji, zwany selekcją zależną od częstości. W jeziorze Tanganika żyją ryby pielęgnicowate, które odżywiają się łuskami innych ryb. Mają one pyski skręcone w prawo lub lewo, mogą więc zerwać łuskę ofiary przepływając równolegle odpowiednio z lewej lub prawej strony. Ryb z pyskiem skręconym w lewo i prawo jest tyle 
samo $^{11}$. Dlaczego tak się dzieje? Wyobraźmy sobie, że wszystkie ryby mają pyski skręcone w prawo. Ryby-ofiary będą zatem obserwować szczególnie czujnie, co dzieje się z ich lewej strony. Zatem mutant z pyskiem skręconym w lewo będzie rzadziej w porę wykrywany, zje więcej i pozostawi więcej potomstwa. Coraz więcej będzie ryb z pyskiem skręconym w lewo, a ryby-ofiary będą coraz równomierniej obserwować co dzieje się z lewej i prawej strony. Gdy częstość obu wariantów wyrówna się, skręcenie pyska w którąś ze stron nie da już żadnej przewagi. Ale gdyby przypadkowo zmniejszyła się częstość „lewoskrętnych”, natychmiast uzyskają one przewagę ${ }^{12}$.

Ten bardzo prosty przykład dotyczący ryb, ma za zadanie uświadomić rolę selekcji zależnej od częstości w kształtowaniu różnych predyspozycji w obrębie plemion. Plemiona posiadające odpowiednią proporcję wodzów, szamanów, wojowników, negocjatorów, sprawnych zbieraczy, itp. odnosiły sukces w walce czy konkurencji z plemionami, w których te proporcje były niewłaściwe. Każda rola wymaga pewnych uzdolnień psychofizycznych i odpowiedniego temperamentu, inaczej rzecz ujmując, innego charakteru czy osobowości. Bycie rzadkim w stosunku do potrzeb być może podnosiło prestiż i dawało lepsze szanse rozrodu, co stabilizowało odpowiednie częstości różnych ról. Jednak jak w przykładzie z rybkami o skręconych pyskach, mamy tu do czynienia z doborem zależnym od częstości: gdy proporcje się wyrównają, dodatkowego zysku już nie ma.

Innym problemem jest utrzymanie zmienności w kwestii przestrzegania reguł. Ludzie mają różną tendencję do przestrzegania reguł. Jeśli w plemieniu było zbyt wielu drobiazgowo przestrzegających reguł, brakowało plastyczności niezbędnej do dostosowywania reguł do zmieniających się warunków, czyli do ewolucji kulturowej. Jeśli z kolei zbyt dużo było lekko traktujących reguły, nie mogły one działać i układ społeczny mógł się załamać lub osłabić na tyle, że plemię przegrywało konkurencję $\mathrm{z}$ innymi. Zmienność w podejściu do reguł istnieje do dziś i byłoby interesujące poznać jej komponent genetyczny, o ile rzeczywiście istnieje.

\footnotetext{
11 T. Goldschmidt, Darwin's Dreampond: Drama on Lake Victoria, Cambridge, Mass. 1996. Polskie tłumaczenie: Wymarzonejezioro Darwina. Dramatw Jeziorze Wiktorii, tłum. M. Betley, Warszawa 1999.

12 Na poziomie nie Darwinowskim lecz kulturowym analogią jest umieszczanie wlotu paliwa z lewej lub prawej strony. Dzięki mniej więcej podobnej częstości obu rozwiązań częstość samochodów podjeżdżających z obu stron dyspozytorów jest podobna.
} 


\section{Rytm, muzyka i taniec}

Wyobraźmy sobie lamparta atakującego grupę praludzi. Możliwe są dwie reakcje: uciekać jak najszybciej albo ruszyć w kierunku drapieżnika w skoordynowany sposób, wykrzykując cokolwiek byle głośno i rytmicznie. Jeśli wybrana zostanie pierwsza strategia, zginie najsłabszy osobnik, w następnym ataku kolejny. Cała grupa prędzej czy później wyginie, o ile straty nie będą kompensowane przez rozród. W przypadku antylop tak się dzieje, ale one szybko dojrzewają i często mają młode. Hominidy musiały wybrać drugą strategię - ich duże mózgi nie pozwalały na tak szybki wzrost i reprodukcję jak u antylop. Czy istnieje lew o dostatecznie lwim sercu, by nie cofnąc się przed grupą pokrzykującą rytmicznie, a być może także uzbrojoną w kije? W plemiennych wojnach grupy zdolne do spektakularnych rytmicznych popisów, zwłaszcza z użyciem nawet prymitywnych instrumentów, mogły także uzyskiwać psychologiczną przewagę i zwyciężać. Możemy założyć, że przyjemność z wytwarzania lub odbierania rytmicznych dźwięków została wcześnie wbudowana w układ nagrody mózgów naszych przodków ${ }^{13}$. Ważne też było rozróżnienie dźwięków wydawanych przez wrogów i sprzymierzeńców, z czego może wywodzić się selekcja w kierunku kreatywności muzycznej.

W literaturze jest wiele dyskusji, czy muzyka wywodzi się z odstraszania drapieżników, uspokajania niemowląt, uwodzenia, czy wreszcie wspólnej skoordynowanej pracy. Takie rozważania są raczej bezsensowne: $\mathrm{z}$ chwilą, gdy rytm zaczął pobudzać układ nagrody w mózgach naszych przodków (zaczął sprawiać przyjemność), muzyka musiała być wykorzystywana we wszystkich możliwych celach. Nawet dziś taniec jest ważnym elementem doboru partnerów, gdyż w nim można łatwo ocenić kondycję partnera. Tańce godowe są zresztą powszechne w przyrodzie, żeby wspomnieć choćby żurawie czy muszki owocowe. Styl tańca jest w przypadku muszek owocowych dobrym sygnałem rozpoznawczym przynależności do danego gatunku, a w przypadku naszych przodków mógł pomagać odróżnić swoich od obcych, bo zapewne każde plemię miało odmienną muzykę i odmienny styl tańca. Co ważne, zbiorowe tańce są elementem rytuałów silnie spajających grupę. Nie przypadkiem istnieją tańce wojenne, bo poczucie wspólnoty

13 Szympansy lubią bębnić i robić hałas, ale nie potrafią utrzymać rytmu. Prawdopodobnie nie mają dostatecznie rozwiniętych w mózgach symulatorów czynności, które po wyćwiczeniu wysyłają z wyprzedzeniem sygnały do mięśni. Przypuszcza się, że symulatory takie powstały pierwotnie lub udoskonaliły w procesie doskonalenia rzutów (małpy niezbyt celnie rzucają), ale wykorzystywane są także do generacji mowy i wielu nietypowych czynności, takich jak pisanie na klawiaturze czy prowadzenie samochodu. 
jest szczególnie ważne, gdy trzeba narażać się na niebezpieczeństwo we wrogiej interakcji z inną grupą ${ }^{14}$. Zdecydowana większość ludzi odczuwa przyjemność przy zbiorowych tańcach czy śpiewach, a tylko dla nielicznych jednostek jest to sytuacja stresująca ${ }^{15}$.

\section{Muzyka i matematyka ${ }^{16}$}

Wiele lat temu zapytałem nauczyciela muzyki, będącego też kompozytorem, czy muzyka ma coś wspólnego z matematyką. Obruszył się, mówiąc: „Muzyka jest matematyką!”. Podobne opinie wyrażało wielu matematyków. Różnica jest taka, że z muzyką czujemy się fizycznie związani bez jakiegokolwiek przygotowania, a matematyki musimy się uczyć i tylko nieliczni wspinają się na takie szczyty, że czytanie pięknego dowodu matematycznego budzi emocje porównywalne do słuchania pięknej muzyki. Nie jest wykluczone, że muzyka jest pramatematyką, a przynajmniej stworzyła predyspozycję do uprawiania matematyki. Prawie wszyscy lubimy muzykę, ale tylko nieliczni matematykę. Jest tak dlatego, że matematyczna struktura muzyki jest głęboko ukryta i potrzeba talentu i ciężkiej pracy, by dostrzec powiązania.

Liczenie było z pewnością bardzo użyteczne w wielu obszarach już u zarania naszych dziejów. Liczenie członków grupy (lub porównywanie liczebności), liczenie stad, dzielenie łupów, porównywanie liczby elementów w zbiorach itp. Można wydedukować, jak zostały odkryte liczby parzyste, nieparzyste, czy nawet liczby pierwsze. Przypuśćmy, że pewna liczba orzechów ma być równo podzielona na wszystkich członków grupy. Pomiędzy dwóch członków grupy można równo podzielić tylko parzystą liczbę orzechów. Jeśli liczba orzechów jest liczbą pierwszą, można równo podzielić tylko wtedy, jeśli liczba orzechów i liczba członków grupy jest taka sama: każdy dostanie jednego orzecha. Ta reguła musiała być odkryta w dalekiej przeszłości. Tak zwane Ishango Bone, narzędzie wykonane z kości pawiana, datowane na 6500 lat pne, a znajdujące się obecnie w Muzeum Historii Naturalnej w Brukseli, ma trzy kolumny nacięć, w każdej cztery grupy. Nacięcia pierwszej kolumny reprezentują liczby 11, 13, 17 i 19, a więc liczby pierwsze z drugiej dziesiątki. Reguła duplikacji jest reprezentowana

$14 \quad$ D. Jones, The ritual animal, "Nature”, 24 stycznia 2013.

15 Wartow tym kontekście przyjrzeć się rytuałom sportowców przed rozpoczęciem meczu w sportach zespołowych.

16 Przedstawiony poniżej wywód na temat ewolucji matematyki ma wydźwięk zdecydowanie antyplatoński. Obiektywny przegląd koncepcji znajdzie czytelnik w książce Bartosza Brożka i Mateusza Hohola Umyst matematyczny, Warszawa 2014. 
w drugiej kolumnie (3 i 6; 4 i 8; 10 i dwa razy 5; 7 i nic, prawdopodobnie kość została w tym miejscu złamana). Liczby 10+1, 10-1, 20+1 i 20-1 Nauka są reprezentowane w trzeciej kolumnie ${ }^{17}$. Nie jest to najstarszy obiekt z zapisem matematycznym. Lemombo Bone datowana na 35000 lat temu zawiera 29 nacięć, co prawdopodobnie związane jest z cyklem księżycowym lub menstrualnym. ${ }^{18}$

Dzielenie dóbr mogło zainspirować także pojęcie ułamków. Znajomość ułamków mogła też być przydatna przy ustalaniu pokrewieństwa, co z kolei było ważne przy aranżacji związków małżeńskich i ustalaniu jak dalece należy się poświęcać dla krewnych. Współczynniki pokrewieństwa stosowane w biologii ewolucyjnej to ułamki zwyczajne: $1 / 2$ dla rodziców i dzieci, a także pełnego rodzeństwa; $1 / 4$ dla rodzeństwa przyrodniego oraz dziadków i wnuków; 1/8 dla kuzynów pierwszego rzędu itd. Czy śledzenie pokrewieństwa było oparte na czystej intuicji, czy kalkulacji jaką część „,wspólnej krwi” mają dwaj osobnicy? Ryszard Kapuściński pisze w Hebanie, że dwóch mieszkańców Afryki tak długo rozmawia o swych krewnych, wioskach i klanach, aż ustalą stopień pokrewieństwa, a wtedy wiedzą już, na co mogą liczyćc ${ }^{19}$.

Matematyka rozwijała się bardzo wolno, jej wielkie odkrycia dzieliły czasem pokolenia. $\mathrm{W}$ dodatku z powodu ograniczonej komunikacji systemy matematyczne rozwijały się często niezależnie w różnych kulturach. Wydaje się, że tylko bardzo prosta matematyka jest naturalna dla naszych umysłów. Bardziej skomplikowanych struktur uczymy się krok po kroku, są one jakby piętrowo ułożone na wcześniejszych strukturach. Ten proces przypomina rozwój języka ${ }^{20}$. Teoria Einsteina nie mogłaby powstać przed Newtonowską matematyką. W podobny sposób każdy z nas z mozołem krok po kroku rozwija swe umiejętności matematyczne, choć niewielu dociera na szczyt.

\section{Język}

Komunikacja wokalna jest powszechna w świecie zwierząt i z pewnością była używana intensywnie obok komunikacji opartej na gestach już przez wczesnych hominidów. Jest prawdopodobne, że komunikacja głosowa działała na zasadzie kodu, podobnie jak u pewnych gatunków

17 Mathematicians of the African Diaspora, http://www.math.buffalo.edu/mad/ Ancient-Africa/ishango.html

$18 \quad$ Tamże.

19 R. Kapuściński, Heban, Warszawa 1998 (pierwsze wydanie).

20 S. Miyagawa, R. C. Bewerwick, K. Okanoya, The emergence of hierarchical structure in human language, "Frontiers in Psychology", February 2013. 
makaków, gdzie poszczególnym dźwiękom są przyporządkowane określone znaczenia, typu wąż, drapieżnik w powietrzu, drapieżnik na ziemi, itp., co pozwala reszcie stada zachować się w sposób zapewniający bezpieczeństwo. Sygnały te nie zawsze są używane uczciwie - obserwowano, że małpy czasem ostrzegają o niebezpieczeństwie na ziemi, by towarzysze uciekli na drzewo i zostawili na ziemi smaczny kąsek. Ale bez wątpienia od takiej komunikacji do języka jest jeszcze daleka droga. Nie wiemy, czy język, w sensie współczesnego języka, pojawił się dopiero u homo sapiens, czy też protojęzyka używał już homo erectus. Hipotezy oparte są na skąpym materiale pozwalającym z pewnym prawdopodobieństwem odtworzyć budowę krtani i na innych pośrednich przesłankach. Osobiście preferuję ten drugi pogląd, czyli występowanie protojęzyka już u wcześniejszych przodków, bo teorie oparte na kontinuum zmian lepiej sprawdzają się w teorii ewolucji. Jest jednak wysoce prawdopodobne, że zasadniczy przełom w używaniu języka nastąpił dopiero u homo sapiens, co przyspieszyło sukces ewolucji poprzez napędzenie rozwoju kultury. Ostatnie badania zdają się wskazywać, że geny umożliwiające mówienie są bliższe genom ptaków odpowiedzialnym za śpiew niż genom małp człekokształtnych odpowiedzialnym za komunikację głosową ${ }^{21}$. Jeśli przypuszczenie to potwierdzi się, będzie wskazówką istotnej informacji. Śpiew ptaków i muzyka ludzi mają wiele wspólnego, są oparte na tym samym układzie harmonicznym. Gdy powstaje piosenka, najczęściej jeden człowiek komponuje melodię, drugi wymyśla tekst, czasami robią to zresztą niezależnie, a dopasowanie tekstu i muzyki wymaga tylko pewnych poprawek. Czyżby przełom w powstawaniu języka polegał na tym, że oparty na symbolach protojęzyk charakterystyczny dla małp człekokształtnych połączył się ze śpiewem „ukradzionym ptakom”? Do dziś Pigmeje Aka używają podczas zbiorowych polowań z nagonką w dżungli specyficznego śpiewu bez słów, może z wplatanymi pojedynczo słowami, do komunikacji. Informują się w ten sposób wzajemnie o swoich pozycjach i napotkanych ofiarach. Łatwo sobie też wyobrazić, że w okresie zbieracko-łowieckim dzieciom (one też od wczesnego dzieciństwa były zbieraczami) łatwo było lokalizować matkę, gdy śpiewała ona, bez względu na to, czy używając słów, czy też nie. Cała grupa czuła się zapewne komfortowo będąc w ,śpiewnym kontakcie”, co mogło być praźródłem przyjemności ze słuchania muzyki ${ }^{22}$.

\section{$21 \quad$ Tamże.}

22 Nasze dzisiejsze pohukiwania podczas zbierania grzybów są dużo mniej skuteczne - po „hop-hop” trudniej zidentyfikować osobę nadającą sygnał. 
Czy jest przypadkiem, że jąkała może łatwiej wyrazić myśl śpiewem niż mową? Czy jest przypadkiem, że poezja, tak bliska muzyce, była Nauka uprawiana od tak dawna? Czy jest przypadkiem, że łatwiej ułożyć muzykę do wiersza niż prozy ${ }^{23}$ ? Czy jest przypadkiem, że muzyka i poezja były od dawna używane do uwodzenia? Pamiętajmy też, że mówimy o melodii poszczególnych języków.

Nie jest jasne jak powstał język, bo hipoteza, że jest hybrydą protojęzyka z dołożoną muzyką ukradzioną ptakom jest tylko hipotezą. Nie jest też jasne, do czego język, już ten prawdziwy, był początkowo używany. Robin Dunbar ${ }^{24}$ argumentuje, że na pewno nie pełnił on prostej roli użytkowej. Zresztą do dziś, jeśli ktoś wydaje jedynie komunikaty, uważamy go za wyjątkowego mruka. Na polowaniu łatwiej porozumiewać się gestami niż mową. Uczony uważa, że podstawowym zadaniem języka u zarania ludzkości było plotkowanie, zastępujące iskanie. Iskanie, bez wątpienia niezwykle ważna aktywność u małp nie tylko ze względów higienicznych, ale przede wszystkim wzmacniająca więzi między osobnikami, angażuje dwa osobniki: iskanego i iskającego. Proste wzory kombinatoryczne pozwalają wyliczyć, ile iskań potrzebnych jest w grupie o danej wielkości, by każdy wszedł $\mathrm{w}$ interakcję z każdym. W toku ewolucji grupy praludzi powiększały się równolegle do powiększania mózgu, dochodząc do około 150 osobników, bo według Dunbara kontakty z tyloma ludźmi jest w stanie „obsłużyć” przeciętny mózg (tzw. liczba Dunbara). Można wyliczyć, że wzajemne iskanie w tak dużych grupach zajęłoby lwią część dnia i nie wystarczyłoby czasu na realną pracę i sen. Plotkowanie jest lepsze, bo można je uprawiać w grupach trzy- czteroosobowych. To ogromna oszczędność czasu. Jako argument autor przywołuje nasze współczesne obyczaje, no i oczywiście przyjemność, jaką odczuwamy obgadując innych ${ }^{25}$.

Nawet jeśli wizja Dunbara jest nieco uproszczona, nie ulega raczej wątpliwości, że język był używany raczej do rozwiązywania problemów socjalnych niż do komunikowania o faktach, do czego wystarczałby protojęzyk oparty na dźwiękach sygnałowych i gestach. Musimy jednak

23 Jednym z przebojów „Piwnicy pod Baranami” był dekret o stanie wojennym. Nie była to poezja, ale jednak dekret składał się z paragrafów - jakby zwrotek. $\mathrm{Z}$ refrenem ,zabrania się”.

$24 \quad$ R. Dunbar, Grooming, Gossip..., dz. cyt.

25 Popularność seriali można tłumaczyć tym, że ich miłośnicy mają wrażenie podglądania życia innych. A to było zawsze ważne, bo po pierwsze pozwalało lepiej ustawić się w układzie lokalnej społeczności, a po drugie dawało materiał do plotek. Popularność serwisów plotkarskich i tabloidów zdaje się potwierdzać hipotezę Dunbara. 
pamiętać, że w historii naszego gatunku środowisko społeczne bardzo wcześnie stało się ważniejsze niż środowisko naturalne.

Jakakolwiek byłaby historia powstania naszego języka, na pewno pełnił specjalną rolę w integracji plemienia. Używamy języka do myślenia o skomplikowanych problemach. Bez języka rozwój myślenia abstrakcyjnego byłby niemożliwy, a zatem nie byłoby możliwe budowanie rozsądnego modelu rzeczywistości. Wprawdzie przypuszczamy dziś, że zwierzęta mają zdolność abstrakcyjnego myślenia, ale na pewno zdolność ta jest rudymentarna w porównaniu z człowiekiem. Uczenie się socjalne, w grupie, pozwala na rozwój komunikacji i wzmacnianie więzów. Używanie tego samego języka pozwala na poziome (między rówieśnikami) i pionowe (między pokoleniami) uzgadnianie modelu (obrazu) świata i reguł obowiązujących w grupie. W ten sposób plemię może akumulować w sposób sensowny wiedzę, a plemiona z lepszym modelem rzeczywistości i lepiej dostosowanymi do okoliczności regułami mogły eliminować, poprzez konkurencję, ale niestety także dosłownie, inne plemiona. Prowadzić to musiało stopniowo do rozwoju języka.

\section{Siła w liczebności}

Plemiona zwycięskie rosły w liczbę i przez to dalej zwiększały swą liczebność. Zdolności muzyczne, artystyczne, matematyczne, inżynierskie i inne mają rozkład zbliżony do normalnego. Oznacza to, że tylko w dużych grupach jest realna szansa spotykania regularnie bardzo uzdolnionych w jakimś kierunku ludzi i wykorzystania ich umiejętności. W małych grupach będzie się to zdarzać tak rzadko, że posiadacze talentów będą traktowani jak dziwacy, jak cielę o dwóch głowach. Ludzie utalentowani w jakimś kierunku mają często deficyty w radzeniu sobie z codziennością. Duża grupa może takich utrzymać, w małej mogą zginąć z głodu. Zatem społeczeństwa muszą być dostatecznie liczne, aby były innowacyjne.

Szybki postęp wymaga wymiany idei. Szansa, że nawet w stosunkowo licznej grupie znajdzie się szereg osób utalentowanych w tym samym kierunku jest niewielka. Istniała krytyczna wielkość populacji (plemienia), która umożliwiała powstanie kultury i technologii, dzięki możliwości wymiany myśli między podobnie uzdolnionymi. Adam Smith poprzez apoteozę podziału pracy dodatkowo przyspieszył spiralę rozwoju. Potem globalizacja zrobiła swoje. Dzięki tym zjawiskom cieszymy się dobrobytem, bujnym rozwojem kultury, niesłychanie szybkim postępem technicznym. Nic jednak za darmo. Nie oczekujmy 
w globalnej wiosce tego samego komfortu życia społecznego, takiego samego przestrzegania reguł, jak w realnych izolowanych wioskach Nauka przeszłości.

\section{Wnioski}

Ewolucja biologiczna i kulturowa naszego gatunku oparta była na licznych sprzężeniach zwrotnych dodatnich, czyli mechanizmach samonapędzających. Dlatego była tak szybka. Zwiększenie liczebności grup i związane z tym powiększanie mózgu, umożliwiające dalsze powiększanie grupy, jest przykładem takiego sprzężenia zwrotnego dodatniego, a zapoczątkowane zostało przejściem do życia na sawannie. Grupy osobników o większych mózgach, liczniejsze, mogły skuteczniej konkurować o pokarm i przestrzeń z mniejszymi grupami. Więcej pokarmu to możliwość utrzymania jeszcze większych mózgów. Naturalna bariera wielkości mózgu, czyli problemy anatomiczne przy porodzie, spowodowały stopniowe przesuwanie rozwoju do okresu postnatalnego, co umożliwiało dalsze powiększanie mózgu - kolejny przykład dodatniego sprzężenia zwrotnego. Przedłużenie okresu rozwoju rozciągnęło okres socjalnego uczenia się, co w komplikujących się układach społecznych dawało szansę na wyższy całożyciowy sukces reprodukcyjny. Stwarzało to nacisk selekcji na dalsze przedłużanie dzieciństwa - kolejne dodatnie sprzężenie zwrotne. Zarysowane w tym artykule mechanizmy nie wymagają gwałtownych skokowych zmian. Nie była potrzebna ani ingerencja sił nadprzyrodzonych, ani wizyta kosmitów, by uczłowieczyć małpę. Wystarczał Darwinowski mechanizm ewolucji, a z czasem także ewolucja kulturowa, możliwa dzięki wcześniejszemu mechanizmowi Darwinowskiemu, no i oczywiście czas, liczony w kilku milionach lat. Jeśli Bóg istnieje i stworzył człowieka, to posłużył się ewolucją, nie specjalnym, zarezerwowanym tylko dla człowieka aktem kreacji. Jak pisze Francisco Ayala ${ }^{26}$, zdejmuje to z Pana Boga odpowiedzialność za wszelkie usterki i niedoróbki charakteryzujące nasz gatunek. Gdybym był Panem Bogiem, jako optymista cieszący się życiem patrząc na ludzkie losy powiedziałbym: „Może nie wyszło wszystko idealnie, ale jednak warto było".

Słowa kluczowe: ewolucja człowieka, ewolucja wielkości mózgu, powstanie układu plemiennego, układ nagrody i kary, ewolucja kulturowa, powstanie języka, początek matematyki.

$26 \quad$ F. J. Ayala, Darwin's Gift to Science and Religion, Washington 2007. Polskie tłumaczenie: Dar Karola Darwina dla nauki i religii, tłum. P. Dawidowicz Warszawa 2009. 